\title{
Anaerobic treatment of activated sludge from Swedish pulp and paper mills - biogas production potential and limitations
}

\author{
Anna Karlsson, Xu-Bin Truong, Jenny Gustavsson, Bo Svensson, \\ Fredrik Nilsson and Jorgen Ejlertsson
}

\section{Linköping University Post Print}

N.B.: When citing this work, cite the original article.

This is an electronic version of an article published in:

Anna Karlsson, Xu-Bin Truong, Jenny Gustavsson, Bo Svensson, Fredrik Nilsson and Jorgen Ejlertsson, Anaerobic treatment of activated sludge from Swedish pulp and paper mills biogas production potential and limitations, 2011, Environmental technology, (32), 14, 15591571.

Environmental technology is available online at informaworld ${ }^{\mathrm{TM}}$ : http://dx.doi.org/10.1080/09593330.2010.543932

Copyright: Taylor \& Francis / Selper

http://www.tandf.co.uk/journals/default.asp

Postprint available at: Linköping University Electronic Press

http://urn.kb.se/resolve?urn=urn:nbn:se:liu:diva-72041 
Anaerobic treatment of activated sludge from Swedish pulp and paper mills - biogas production potential and limitations

Anna Karlsson ${ }^{1 *}$, Xu-Bin Truong ${ }^{2}$, Jenny Gustavsson ${ }^{1}$, Bo H Svensson ${ }^{1}$, Fredrik Nilsson $^{3}$ and Jörgen Ejlertsson ${ }^{2}$

${ }^{1}$ Department of Water and Environmental Studies, Linköping University, 58183 Linköping

${ }^{2}$ Scandinavian Biogas Fuels AB, WTC, Kungsbron 1, 11122 Stockholm

${ }^{3}$ Pöyry Sweden AB, Hotellgatan 5, 60222 Norrköping

*Corresponding author: annka@tema.liu.se, Phone: +4613284089, Fax:

$+4613133630$ 


\title{
Anaerobic treatment of activated sludge from Swedish pulp and paper mills - biogas production potential and limitations
}

\author{
The methane potential of activated sludge from six Swedish pulp and paper mills was \\ evaluated. The methane production potential of sludge samples ranged from 100 to $200 \mathrm{NmL}$ \\ $\mathrm{CH}_{4} \mathrm{~g}^{-1}$ volatile solids (VS) and for four of the six sludge samples the potential exceeded \\ $170 \mathrm{NmL} \mathrm{CH}_{4} \mathrm{~g}^{-1} \mathrm{VS}$. The effects of sludge age and dewatering on the methane production \\ potential were evaluated. The effects of enzymatic and ultrasonic pre-treatment on the \\ digestibility of sludge were also investigated, but energy or enzyme inputs in viable ranges did \\ not exert a detectable, positive effect. Long-term, semi-continuous trials with sludge from two \\ of the mills were also conducted in attempts to develop stable biogas production at loading \\ rates up to $4 \mathrm{~g} \mathrm{VS} \mathrm{L}^{-1}$. Cobalt addition $\left(0.5 \mathrm{mg} \mathrm{L}^{-1}\right)$ was here found to positively affect the \\ turnover of acetate. High viscosity was a problem in all the experimental reactors and this \\ limited the organic loading rate.
}

Keywords: Pulp and paper industry, anaerobic digestion, activated sludge, trace elements, pretreatment

\section{Introduction}

Large volumes of wastewater are produced within the Swedish pulp and paper industry. Most of this water is currently treated using activated sludge processes. The resulting sludge is normally dewatered and incinerated or, for a fee, treated and used for purposes such as filling material [1]. The treatment of wastewater incurs a cost for the mills and does not make use of its potential energy and nutrient content. Another option that can potentially exploit these resources is anaerobic digestion (AD). AD has been implemented and, in some cases, evaluated for the treatment of pulp and paper mill wastewater[2-6]. Depending upon the strategy chosen, AD may have several benefits compared to aerobic techniques: the incoming wastewater can be treated directly in an upflow anaerobic sludge blanket (UASB) reactor or a similar high rate system, followed by an activated sludge bed for final treatment of the remaining organic matter. The sludge from the aerated process (with or without pre-treatment in an UASB system) can then be digested to generate biogas in a completely stirred tank reactor (CSTR). The advantages of this treatment strategy include reduction of the sludge volume by $30-70 \%$ [7] and the production of biogas. AD can also improve the compatibility 
of sludge with the dewatering process, but this effect seems to depend on the degree of reduction of organic matter [8]. Anaerobic treatment processes also release nutrients into the liquid and thus into the reject water. This nutrient-rich reject water can be re-circulated to the aerobic activated sludge biological process, thereby reducing the need for commercial nitrogen and phosphorus fertilizers to support this function.

In addition, pre-treatment can further improve the reduction of organic matter, decrease sludge volumes and increase biogas production. Numerous pre-treatment methods have been tested, especially for complex substrates such as lignocellulosic biomass [9] and municipal solid waste [10]. A number of methods have also been evaluated for treating "bio-treatment residues" from the pulp and paper industry [7]. The latter researchers concluded that ultrasound techniques are potentially suitable for treating sludge produced from pulp and paper mills, mainly from experience of treating activated sludge from other sources.

Hydrolytic enzyme treatments have also been shown to enhance the degradation of activated sludge [11-13].

As discussed above, anaerobic treatment of waste water from pulp and paper processing has several benefits, depending on the extent of implementation. The energy trapped in the organic matter can be transferred to methane for the production of vehicle fuel or electricity and the nutrients in the anaerobic digestate can be used as fertilizer for arable land or forests (assuming that they comply with restrictions on trace metal content. Power consumption and the need of commercial nutrient (nitrogen and phosphorus) for the aerobic biological process can also be reduced, since less aeration and external nutrient additions is needed for the active sludge process when combined with anaerobic treatment.

As a first step towards improving the resource utilization efficiency of wastewater treatment at Swedish pulp and paper mills using anaerobic techniques, the methane production potential was evaluated for biological sludge from six Swedish mills (Table 1). These comprised two integrated pulp- and paper mills using mechanical pulp (Mills 1 and 6) and four mills with chemical pulp production processes; one Kraft pulp mill (Mill 3), one pulp and board mill using chemi thermo mechanical pulp (CTMP) and Kraft pulp (Mill 4), one board mill using Kraft pulp and externally produced CTMP (Mill 5) and one integrated paper mill producing fine paper from sulphite pulp (Mill 2). 
Table 1 Characteristics for the six studied mills. TMP= thermo mechanical pulp; DIP= deinked pulp; $\mathrm{CTMP}=$ chemi thermo mechanical pulp; $\mathrm{AP}=$ aerated pond; $\mathrm{ASB}=$ activated sludge basin; $\mathrm{LASB}=$ long term aerated sludge basin. All mills have a separation of suspended material.

\begin{tabular}{lllll}
\hline & Type of pulp & & \multicolumn{1}{c}{ Product } & \multicolumn{2}{c}{ Water purification } \\
\hline Mill 1 & TMP/DIP & newsprint & modified AP & yes \\
Mill 2 & sulphite & wood-free printing paper & ASB & no \\
Mill 3 & Kraft & pulp & ASB & no \\
Mill 4 & CTMP and Kraft & board & AP & yes \\
Mill 5 & CTMP ${ }^{1}$ and Kraft & board & LASB & no \\
Mill 6 & TMP & newsprint/improved newsprint & ASB (2-stage) & no \\
\hline
\end{tabular}

${ }^{1}$ externally produced

The mills were selected to represent the different types of production line and wastewater treatment systems used in the Swedish pulp and paper industry, see Table 1 for details. The effect of ultrasound pre-treatment on methane production potentials was investigated on sludge from Mills 3 and 5 and the effect of hydrolytic enzyme pre-treatment on methane production potentials was investigated on sludge from Mill 5. These pre-treatment methods were evaluated because they have been shown to be effective for sludge from sewage water treatment $[7,11-13]$, but have not been extensively tested on sludge from the pulp and paper industry to the authors' knowledge. Activated sludge from two of the mills was further tested in laboratory-scale, continuously-stirred tank reactors (CSTRs) to determine the optimum organic loading rate (including the effects of trace element addition) and to identify possible limitations for applications in full-scale plants. Pre-treatment with hydrolytic enzymes was included in the CSTR experiments.

\section{Materials and Methods}

\section{Batch experiments}

The methane production potential of activated sludge from the six mills (Table 1) was evaluated in a series of assays, with conditions shown in Table 2, using $300 \mathrm{~mL}$ serum bottles, sealed with rubber stoppers and aluminium screw caps. Activated sludge (amounts are indicated as organic load in Table 2), inoculum (reactor material from a nearby waste water treatment plant; $20 \mathrm{~mL}$ ), salts $\left(\mathrm{NH}_{4} \mathrm{Cl}, 0.3 \mathrm{~g} \mathrm{~L}^{-1} ; \mathrm{NaCl}, 0.3 \mathrm{~g} \mathrm{~L}^{-1} ; \mathrm{CaCl}_{2} .2 \mathrm{H}_{2} \mathrm{O}, 0.1 \mathrm{~g} \mathrm{~L}^{-1}\right.$; and $\mathrm{MgCl}_{2} \cdot 6 \mathrm{H}_{2} \mathrm{O}, 0.1 \mathrm{~g} \mathrm{~L}^{-1}$ ) and oxygen-free water (Millipore ${ }^{\circledR}$; boiled for $20 \mathrm{~min}$.) were added to 
Table 2. Experimental set-up details for the batch assays, including: the mills sampled; methane potential in NmL $\mathrm{g}^{-1}$ VS ( \pm standard deviation) after $\sim 20$ days (sampling points ranging from day 17-22) and final; total solids content of the sampled sludges (TS; \% of wet weight, WW); sludge age and sampling point at the mills; organic load in g volatile solids $\mathrm{L}^{-1}$; and pre-treatments (US = ultrasound, Enz = enzymes).

\begin{tabular}{|c|c|c|c|c|c|c|c|c|c|c|c|}
\hline \multirow{2}{*}{$\begin{array}{c}\mathrm{Nr} \\
1 \\
\end{array}$} & \multirow{2}{*}{$\begin{array}{l}\text { Mill }^{1} \\
\text { Batch } 1 \\
\text { Mill 1; mech }\end{array}$} & \multirow{2}{*}{$\begin{array}{c}\text { Days } \\
34 \\
\end{array}$} & \multicolumn{2}{|c|}{$\begin{array}{l}\text { Methane } \\
\text { day } 20\end{array}$} & \multicolumn{2}{|c|}{$\begin{array}{l}\text { Methane } \\
\text { final }\end{array}$} & \multicolumn{2}{|c|}{$\begin{array}{l}\text { Sludge age (days) and } \\
\text { sampling point }\end{array}$} & \multirow{2}{*}{$\begin{array}{r}\begin{array}{c}\text { TS at } \\
\text { sampling }\end{array} \\
1.3 \\
\end{array}$} & \multirow{2}{*}{$\begin{array}{c}\text { Organic load } \\
3.2 \\
\end{array}$} & \multirow[t]{2}{*}{$\begin{array}{l}\text { Pre- } \\
\text { treatment }\end{array}$} \\
\hline & & & 118 & $( \pm 25)$ & 138 & $( \pm 24)$ & 15; & b dewa & & & \\
\hline & Batch 2 & & & & & & & & & & \\
\hline 2 & Mill 2; sulphite & 91 & 87 & $( \pm 1)$ & 159 & $( \pm 4)$ & 20 & b dewa & 0.9 & 4.9 & \\
\hline 3 & Mill 2 & 91 & 103 & $( \pm 1)$ & 176 & $( \pm 2)$ & 20; & a dewa & 2.0 & 12.2 & \\
\hline 4 & Mill 3; Kraft & 91 & 69 & $( \pm 14)$ & 145 & $( \pm 10)$ & 5 & b dewa & 0.6 & 3.4 & \\
\hline 5 & Mill 3 & 91 & 110 & $( \pm 4)$ & 188 & $( \pm 3)$ & 5 & a dewa1 & 5.6 & 18.9 & \\
\hline 6 & Mill 3 & 91 & 117 & $( \pm 2)$ & 182 & $( \pm 1)$ & 5 & a dewa2 & 11.6 & 14.7 & \\
\hline 7 & Mill 3 & 91 & 107 & $( \pm 4)$ & 175 & $( \pm 5)$ & $5 ;$ & dewa+a dewa $1^{3}$ & 3.8 & 12.4 & US;2 Wh L ${ }^{-1}$ \\
\hline \multirow[t]{2}{*}{8} & Mill 3 & 91 & 104 & $( \pm 1)$ & 173 & $( \pm 1)$ & $5 ;$ & dewa+a dewa $1^{3}$ & 3.8 & 12.4 & US; $3{W h L^{-1}}^{-1}$ \\
\hline & Batch 3 & & & & & & & & & & \\
\hline 9 & Mill 4; CTMP/Kraft & 114 & 43 & $( \pm 4)$ & 97 & $( \pm 3)$ & 20 & b dewa & 1.1 & 6.7 & \\
\hline 10 & Mill 5; kraft/CTMP & 114 & 98 & $( \pm 5)$ & 167 & $( \pm 4)$ & 14; & b dewa & 0.7 & 3.9 & \\
\hline 11 & Mill 5 & 114 & 95 & $( \pm 2)$ & 155 & $( \pm 5)$ & 14 & a dewa & 4.3 & 14.2 & \\
\hline 12 & Mill 5 & 114 & 96 & $( \pm 2)$ & 158 & $( \pm 1)$ & 14 & a dewa & 4.3 & 14.9 & US; $5 \mathrm{Wh} \mathrm{L}^{-1}$ \\
\hline \multirow[t]{2}{*}{13} & Mill 5 & 114 & 101 & $( \pm 3)$ & 162 & $( \pm 2)$ & 14 & a dewa & 4.3 & 14.9 & US;15 Wh L ${ }^{-1}$ \\
\hline & Batch 4 & & & & & & & & & & \\
\hline 14 & Mill 6; mech & 55 & 155 & $( \pm 3)$ & 197 & $( \pm 5)$ & 7 & b dewa & 1.3 & 6.6 & \\
\hline \multirow[t]{2}{*}{15} & Mill 6 & 55 & 51 & $( \pm 2)$ & 89 & $( \pm 3)$ & 10 & b dewa & 1.1 & 6.9 & \\
\hline & Batch 5 & & & & & & & & & & \\
\hline 16 & Mill 5 & 89 & 132 & $( \pm 5)$ & 199 & $( \pm 5)$ & 14 & a dewa & 3.2 & 10.5 & \\
\hline 17 & Mill 5 & 89 & 178 & $( \pm 1)$ & 240 & $( \pm 5)$ & 14 & a dewa & 3.2 & 10.5 & $\mathrm{Enz} ; 40 \mathrm{mg} \mathrm{g}^{-1} \mathrm{TS}$ \\
\hline 18 & Mill 5 & 89 & 148 & $( \pm 1)$ & 209 & $( \pm 5)$ & 14 & a dewa & 3.2 & 10.5 & US; $30 W h ~ L^{-1}$ \\
\hline 19 & Mill 5 & 89 & 196 & $( \pm 6)$ & 239 & $( \pm 20)$ & 14 & a dewa & 3.2 & 10.5 & $\begin{array}{l}\text { US; } 30 \mathrm{Wh} \mathrm{L}^{-1}+ \\
\text { Enz; } 40 \mathrm{mg} \mathrm{g}^{-1} \mathrm{TS}\end{array}$ \\
\hline
\end{tabular}

${ }^{1}$ mech=mechanical pulp and paper mill; sulphide=pulp and paper mill; Kraft= Kraft pulp mill; CTMP/Kraft= CTMP (chemi thermo mechanical pulp)/Kraft pulp \& board mill; Kraft/CTMP=board mill using Kraft pulp and external CTMP

${ }^{2}$ Sampling points: before dewatering=b dewa and after dewatering=a dewa. Mill 3 had two sampling points: a dewa1 after a dewatering table and a dewa2 after the final centrifugation

${ }^{3}$ 2:1 dilution of sample from a dewa1 with material from $b$ dewa due to difficulties in pumping the dewatered sludge in connection to the ultrasound treatment 
each bottle to a final volume of $100 \mathrm{~mL}$ while flushing with $\mathrm{N}_{2}$. The headspace gas in the bottles was then replaced with $\mathrm{N}_{2}: \mathrm{CO}_{2}(80: 20)$ and $0.3 \mathrm{~mL} 100 \mathrm{mM} \mathrm{Na}_{2} \mathrm{~S}$ was added to each bottle. Two reference samples were included in each set of experiments: inoculum controls without added substrate and positive controls, for which $0.5 \mathrm{~g}$ cellulose (Whatman filter paper No 3) was added as a substrate. All tests were performed in triplicate and the bottles were incubated in the dark at $37^{\circ} \mathrm{C}$.

\section{Reactor set up}

CSTRs with a working volume of $4 \mathrm{~L}$ were used in a semi-continuous lab-scale experiment to investigate the formation of biogas from activated sludge from Mills 3 and 6. The reactors were equipped with a tube, through which substrate was added and reactor material was withdrawn, a gas outlet and a centrally placed impeller $(\varnothing: 70 \mathrm{~mm})$ for mixing, driven by a servomotor (MAC050-A1; All motion Technology) at $500 \mathrm{rpm}$ for 15 minute periods four times per day and for about 10 minutes when adding substrate. Four reactors were used: two for the sludge from each mill; one reference (D3-R and D6-R, respectively) and one with enzyme additions (D3-E and D6-E, respectively). All four reactors were initially loaded with 3.5 $\mathrm{L}$ of material from a reactor treating sewage sludge (above) and $0.5 \mathrm{~L}$ of cow manure. The hydraulic retention time (HRT) for the first 50 days was 20 days, but the HRT was then allowed to fluctuate between 18 and 22 days depending on the volatile solids (VS) content of the sludge that was delivered weekly. Initially, the organic loading rates were 1.2 and $2.7 \mathrm{~g}$ VS L ${ }^{-1}$ day $^{-1}$ for set D3 and set D6, respectively. The organic loading rates was increased over time with setbacks due to process problems, i.e. high viscosity (see below) or low VS content of the sludge. The loadings are given in figures $4 \mathrm{a}$ and $\mathrm{b}$ in the results section. All four CSTRs were operated for 276 days, and they were operated in parallel (D3 and D6, respectively) for 117 days before enzyme addition began. The reactors were operated in the dark at $37^{\circ} \mathrm{C}$.

From day 34 onwards, $\mathrm{FeCl}_{2}\left(0.3-0.5 \mathrm{~g} \mathrm{Fe} \mathrm{L}^{-1}\right)$ was added to the D6-set to reduce $\mathrm{H}_{2} \mathrm{~S}$ levels in the produced gas, and $\mathrm{CoCl}_{2} \cdot 2 \mathrm{H}_{2} \mathrm{O}\left(0.5 \mathrm{mg} \mathrm{Co} \mathrm{L}^{-1}\right)$ was added to D3-R from day 194 and to D3-E from day 260. 


\section{Analysed parameters}

The total gas production in each bottle of the batch experiment was determined by measuring the over pressure in the bottles using a 5-mL glass syringe (Fortuna Optima®, SigmaAldrich). These measurements were normally performed on days 2, 5, 11, 20, 35 and in most cases on days 60 and 90 of incubation. Samples for methane analysis were taken from the gas phase on each sampling occasion before the pressure in the bottle was returned to ambient. The methane content of the headspace gas was determined by gas chromatography [14]. Gas was sampled at $37^{\circ} \mathrm{C}$ and the gas released was accounted for when calculating the methane potentials.

For the reactor experiment, daily total gas production was monitored using gas-meters based on the principle of water displacement. The methane content of the produced gas was measured once a week by collecting the gas in a balloon for $24 \mathrm{~h}$, the gas composition was determined using a portable gas detector (Gas data Ltd., GFM series; Whitley, UK), which also gave the $\mathrm{CO}_{2}, \mathrm{O}_{2}$ and $\mathrm{H}_{2} \mathrm{~S}$ contents. Reactor liquid samples were withdrawn twice a week for the measurement of volatile fatty acid (VFA) concentrations (i.e. acetic, propionic, butyric, isobutyric, capronic, isocapronic, valeric and isovaleric acids) as described by Jonsson and Borén [15]. The pH was measured at least twice a week, while TS and VS were determined once a week following Swedish Standard methods (SS-EN 12176 and SS 028113, respectively).

All gas volumes were normalized to 1 atm pressure and $0^{\circ} \mathrm{C}$ and expressed as "normalised $\mathrm{mL} "(\mathrm{NmL})$.

Reactor liquid viscosity was determined by the Ljunga Laboratory, Ljungaverk, Sweden, in samples taken from the four reactors on days 110, 228 and 272.

\section{Pre-treatments}

\section{Ultrasound}

The effect of ultrasonic pre-treatment of the activated sludge on methane production was investigated using batch incubation (as above) of sludge from Mills 3 and 5 (Table 2). Five energy levels were tested: $2,3,5,15$ and $30 \mathrm{Wh} \mathrm{L}^{-1}$. The equipment used for the ultrasonication tests was constructed and supplied by Scandinavian Biogas Fuels AB, Stockholm, Sweden. 


\section{Enzyme addition}

Batch

The effect of pre-treatment by hydrolytic enzymes (a mixture of cellulases, proteases and lipases provided by a Swedish manufacturer) on methane production was investigated using sludge from Mill 5 (Table 2). The enzyme mixture (40 $\mathrm{mg} \mathrm{g}^{-1}$ total solids (TS)) was added to the sludge at the beginning of batch experiments. A chelating agent containing citric acid was also added at a final concentration of $2 \mathrm{mM}$.

\section{CSTR}

The effect of enzyme addition was also tested in the reactor experiment. Sludge from both mills was treated from day 118 (D3-E and D6-E). The daily dosing schedule is shown in Table 3. An initial dose (day 118) was administered to reach the target concentration of 1.0 $\mathrm{mg} \mathrm{g}^{-1} \mathrm{TS}$ in the reactors. For each daily addition the sludge was mixed (1-2 minutes in one litre batches) using a kitchen blender (Braun Multiquick MR4050; $450 \mathrm{~W}$ ) after which the chelating agent was added and the sludge transferred to the reactor. As no effect of the enzyme treatment was observed after the first week other addition procedures were tested: 1) adding enzyme solution and chelating agent to the sludge, then mixing and adding sludge to the reactor (days 139-141), 2) incubating the activated sludge portion with enzyme solution and chelating agent for $24 \mathrm{~h}$ at $20^{\circ} \mathrm{C}$ and $37^{\circ} \mathrm{C}$ before transfer to the reactor during days 151152 and 153-158, respectively.

Table 3. Addition of enzymes and chelating agent during the laboratory-scale reactor experiment. The amount of enzyme solution (Enz. sol.) added is given as $\mathrm{mg}$ per gram added TS (total solids). The concentration of the chelating agent (Chel. ag.) given in the table is the final concentration in the reactors.

\begin{tabular}{crrrr}
\hline Period & $\begin{array}{c}\text { Mill 3 } \\
\text { Enz. sol. } \\
\text { (mg g }\end{array}$ & $\begin{array}{c}\text { Chel. ag. } \\
\text { (mM) }\end{array}$ & $\begin{array}{c}\text { Mill 6 } \\
\text { Enz. sol. } \\
\text { (mg g }^{-1} \text { TS) }\end{array}$ & $\begin{array}{c}\text { Chel. ag. } \\
\text { (mM) }\end{array}$ \\
\hline Day 118 & 80 & 2 & 80 & 2 \\
Day 119-166 & 1 & 1 & 1 & 1 \\
Day 167-210 & 2 & 1 & 2 & 1 \\
Day 211-222 & 2 & 4 & 2 & 4 \\
Day 223-236 & 8 & 12 & 8 & 12 \\
Day 237-241 & 8 & 25 & 8 & 25 \\
Day 242-255 & 8 & 25 & 80 & 40 \\
Day 256-262 & 80 & 2 & 60 & 2 \\
Day 263-272 & 80 & 2 & 40 & 2 \\
\hline
\end{tabular}




\section{Dewatering of sludge substrate for the CSTR experiment}

Before weekly dispatch to the laboratory, sludge samples from Mill 6 were dewatered manually. From day 167 until the end of the experiment, the TS of the incoming sludge was normally 1-3\% and further dewatering in the laboratory was thus necessary: Sludge was frozen $\left(-20^{\circ} \mathrm{C}\right)$ until solid, thawed, centrifuged at $16500 \mathrm{~g}$ for 20 minutes and finally compressed using a cloth, to achieve TS levels of 4.3 to $8.6 \%$. The sludge from mill 3 was possible to obtain at three different TS levels; 1) non-dewatered, 2) dewatered using a dewatering table (5-8\% TS) and 3) centrifuged (this treatment is performed on sludge from step $2 ; 10-15 \%$ TS).

\section{Dewatering of reactor liquid (process residue)}

The compatibility of digested sludge (reactor liquid) with dewatering was evaluated for samples collected over two weeks (days 243-257). The collected sludge was stored at $4{ }^{\circ} \mathrm{C}$ for up to 14 days. The sludge from each reactor was then divided into six portions, each of 200$225 \mathrm{~g}$, which were weighed and centrifuged at $4420 \mathrm{~g}$ for $20 \mathrm{~min}$. The supernatant and sediment were separated and weighed individually. The samples from each reactor (both the dewatered residue and reject water) were pooled and sent to Eurofins Analycen in Lidköping, Sweden for the determination of TS and VS. Undigested sludge was treated in the same way.

\section{Reduction of viscosity}

The activated sludge from both mills (3 and 6) used for the CSTRs generated reactor liquids with high viscosity leading to incomplete mixing, such that only the material closest to the reactor centre was fully homogenised. Viscosity-related problems were also encountered in the withdrawal and addition of material to the reactors. In order to reduce the viscosity of the activated sludge that was added to the reactor, all sludge portions were mixed using the kitchen blender (as described above) from day 132. From day 169 for reactors D3-R and D3E and from day 211 for reactors D6-R and D6-E, sludge portions were also frozen (at $-20^{\circ} \mathrm{C}$ until solid) and thawed before addition to the reactors. 


\section{Results}

\section{Methane production potential, batch experiments}

To evaluate methane production potentials, activated sludge from wastewater treatment at each of the six mills was incubated for between 34 and 114 days (Fig. 1). The amounts of methane produced after 20 days and the final values for all incubation regimes are given in Table 2. The final methane production potential of sludge from the mills ranged $100-200$ $\mathrm{NmL} \mathrm{CH}_{4} \mathrm{~g}^{-1}$ VS. The highest initial methane formation rate (days 0-5) was obtained using sludge from Mill 6, followed in declining order by Mills 1 and 5, Mills 2 and 3 and finally Mill 4 (Fig. 1).

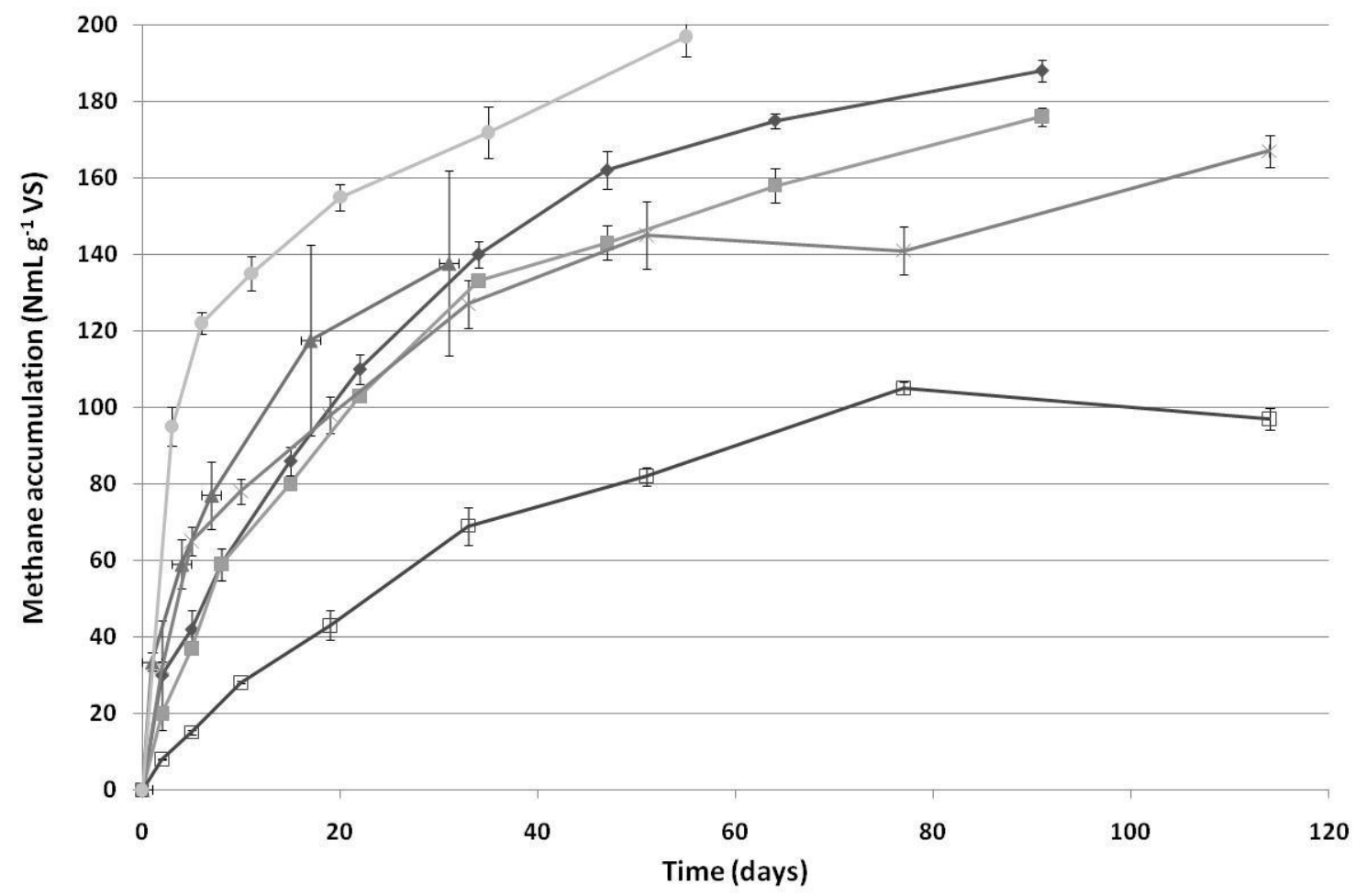

Figure 1. Accumulated methane over time $\left(\mathrm{NmL} \mathrm{g}^{-1} \mathrm{VS}\right)$ for sludge from mills: $1(-\rightarrow), 2$ $(--), 3(\multimap), 4(\square), 5(\multimap)$ and $6(-)$ during the batch assay, corrected for inoculum control. Bars indicate standard deviation. The batch data in the figure correspond to numbers 1: $1,3,5,9$ and 14 in Table 2.

\section{Influence of dewatering/TS-content on the biogas potential}

Sludge was taken from three sampling points at Mill 3 to investigate the influence of TS content on methane production potential: directly from the aerobic treatment basin $(0.6 \% \mathrm{TS}$, 
$\mathrm{VS}=70 \%$ of TS), and after the two dewatering steps; at $5.6 \% \mathrm{TS}, \mathrm{VS}=84 \%$ of TS and $12 \%$ $\mathrm{TS}, \mathrm{VS}=85 \%$ of TS (batch numbers 4, 5 and 6 in Table 2). The two dewatered sludge samples had methane production potentials ( \pm standard deviation (SD)) of $188 \pm 3$ and $182 \pm 1$ $\mathrm{NmL} \mathrm{CH}_{4} \mathrm{~g}^{-1} \mathrm{VS}$, respectively, while a lower potential $(145 \pm 10 \mathrm{NmL})$ was measured for the non-dewatered sludge.

\section{Sludge age}

The incubation of sludge samples from the two aerated basins of Mill 6, which represent different sludge ages (numbers 14 and 15 in Table 2) resulted in clear differences (Fig. 2). Sludge from the first sampling point gave about two times as much methane (age 7 days, $197 \pm 5 \mathrm{NmL} \mathrm{CH}_{4} \mathrm{~g}^{-1} \mathrm{VS}$ ) as sludge from the second treatment (age 10 days, $89 \pm 3 \mathrm{NmL} \mathrm{CH}_{4}$ $\left.\mathrm{g}^{-1} \mathrm{VS}\right)$.

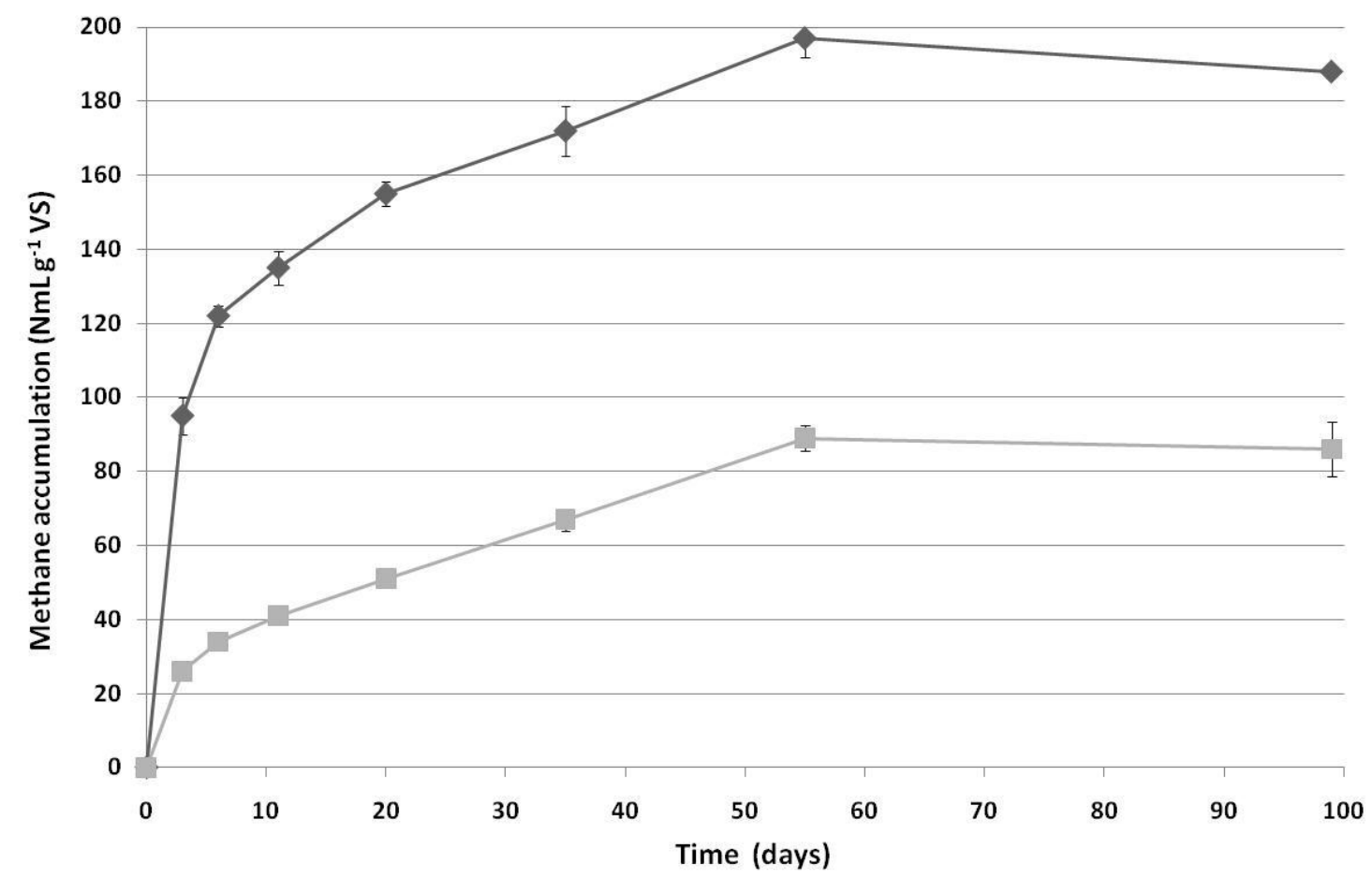

Figure 2. Accumulated methane over time ( $\left.\mathrm{NmL} \mathrm{g}^{-1} \mathrm{VS}\right)$ from bio-treatment of sludge from Mill 6 with $7(\bullet)$ and $10(--)$ days retention time, corrected for inoculum control. Bars indicate standard deviation. 
The influence of ultrasound on the methane production potential was evaluated using sludge from Mills 3 and 5 (batch numbers 7, 8, 12,13, 18 and 19 in Table 2). The application of energy at levels of $2,3,5$ and $15 \mathrm{Wh} \mathrm{L}^{-1}$ did not have a discernible effect on methane production potential when compared to untreated sludge (Table 2). The energy input was increased to $30 \mathrm{Wh} \mathrm{L}^{-1}$ in a setup investigating both ultrasonic and enzyme treatments and their combination using sludge from Mill 5 (17-19 in Table 1). The main effect of ultrasonic treatment in this case was on the initial methane production rate (Fig. 3). When compared to untreated sludge, the largest differences in methane production potential were observed for treatment with ultrasound alone after four days $\left(+27 \mathrm{NmL} \mathrm{CH}_{4} \mathrm{~g}^{-1} \mathrm{VS}\right.$, corresponding to a 44 $\%$ increase) and for treatment with both ultrasound and enzymes after eight days $(+78 \mathrm{NmL}$ $\mathrm{CH}_{4} \mathrm{~g}^{-1} \mathrm{VS}$, equivalent to a $75 \%$ increase in methane production potential). The effects subsequently decreased over time (Fig. 3). The most significant effect of hydrolytic enzyme treatment on the methane production potential (17 in Table 1) was reached after eight days of incubation; an increase of $50 \mathrm{NmL} \mathrm{CH}_{4} \mathrm{~g}^{-1} \mathrm{VS}$ over the control sample value, equivalent to an enhancement of about 50\% (Fig. 3). However, it should be noted that degradation of the enzymes and chelating agent may liberate 19-37 $\mathrm{NmL} \mathrm{CH}_{4} \mathrm{~g}^{-1} \mathrm{VS}$ (based on data obtained from the manufacturers).

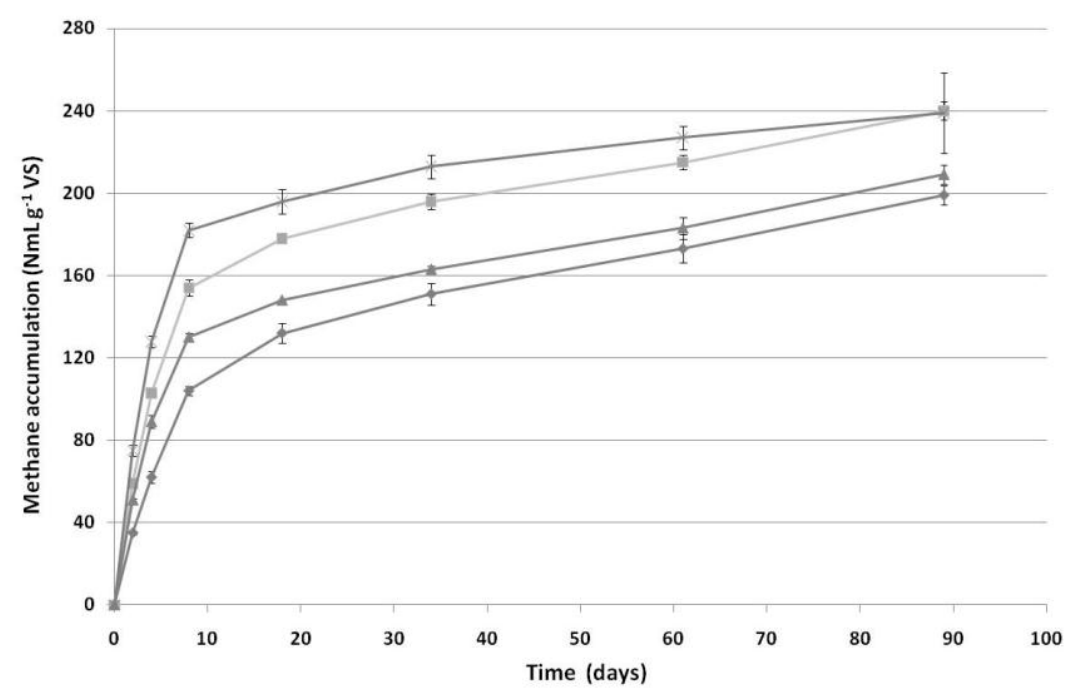

Figure 3. Accumulated methane over time $\left(\mathrm{NmL} \mathrm{g}^{-1} \mathrm{VS}\right)$ from pre-treated sludge from mill 5: enzyme $(--)$, ultrasonic $(\neg)$, enzyme/ ultrasonic $(\star-)$ and untreated $(\neg)$, corrected for inoculum control. Bars indicate standard deviation. 


\section{Semi-continuous reactor experiments}

Apart from acetate and propionate, VFAs were not detected at concentrations $>1 \mathrm{mM}$ during the reactor experiments. Thus, only acetate and propionate concentrations are discussed below.

\section{General performance}

Biogas $\left(\mathrm{CH}_{4}+\mathrm{CO}_{2}\right)$ production ( $\mathrm{NmL} \mathrm{g}^{-1} \mathrm{VS}$ added) and organic loading data for reactors D3$\mathrm{R}$ and D3-E over time are presented in figure $4 \mathrm{a}$ and for reactors D6-R and D6-E in figure $4 \mathrm{~b}$. The sludge from Mill 3 generated about $200 \mathrm{NmL}$ of biogas per g added VS and day (based

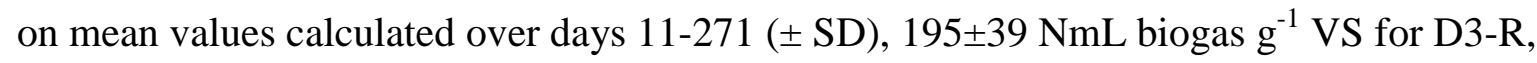
and $195 \pm 44 \mathrm{NmL}_{\text {biogas }} \mathrm{g}^{-1} \mathrm{VS}$ for D3-E). The methane content of the biogas was around $60 \%$ for both reactors. The generation of biogas from the D6 reactors was higher: the production of increased slightly from about $300 \mathrm{NmL} \mathrm{g}^{-1} \mathrm{VS}$ during days $11-110$, to $340 \mathrm{NmL}$ $\mathrm{g}^{-1}$ VS during days 111-271. The methane content was around $56 \%$ for these two reactors. The initial $\mathrm{H}_{2} \mathrm{~S}$ content of the gas from the D6 reactors exceeded $2000 \mathrm{ppm}$. After the addition of $\mathrm{FeCl}_{2}$ from day 34 onward, the $\mathrm{H}_{2} \mathrm{~S}$ levels declined to below $50 \mathrm{ppm}$. The $\mathrm{H}_{2} \mathrm{~S}$ concentration in gas from the D3 reactors was below 400 ppm during the whole experiment except for around 1300 ppm on days 200-228, which was probably caused by disturbances in the wastewater treatment system at the mill.

The mean reduction in VS across all reactors was about $40 \%$ but large variations occurred, probably due to losses of sludge during withdrawal and addition of material to the reactors. Variation in $\mathrm{pH}$ of the reactors seemed linked to the substrate. During the first weeks of the experiment, the $\mathrm{pH}$ of both reactor pairs was around 7.3 (data not shown). In the D3 reactors the $\mathrm{pH}$ subsequently increased slightly over time, reaching around 7.8 at the end of the study, temporary dips (from 7.6 to 7.3) could however be observed around day 200. The $\mathrm{pH}$ of the D6 reactors decreased to 6.8-6.9 during days 50-90, but then increased to final values around 7.0 for reactor D6-R and 7.3 for reactor D6-E, The $\mathrm{pH}$ of the activated sludge delivered from Mills 3 and 6 was 6.1 and 4.8, respectively.

The viscosity increased with the organic load for all reactors (Table 4). Data from the dewatering by centrifugation at $4420 \mathrm{~g}$ for 20 min showed an increase in TS of ca $45 \%$ for the 

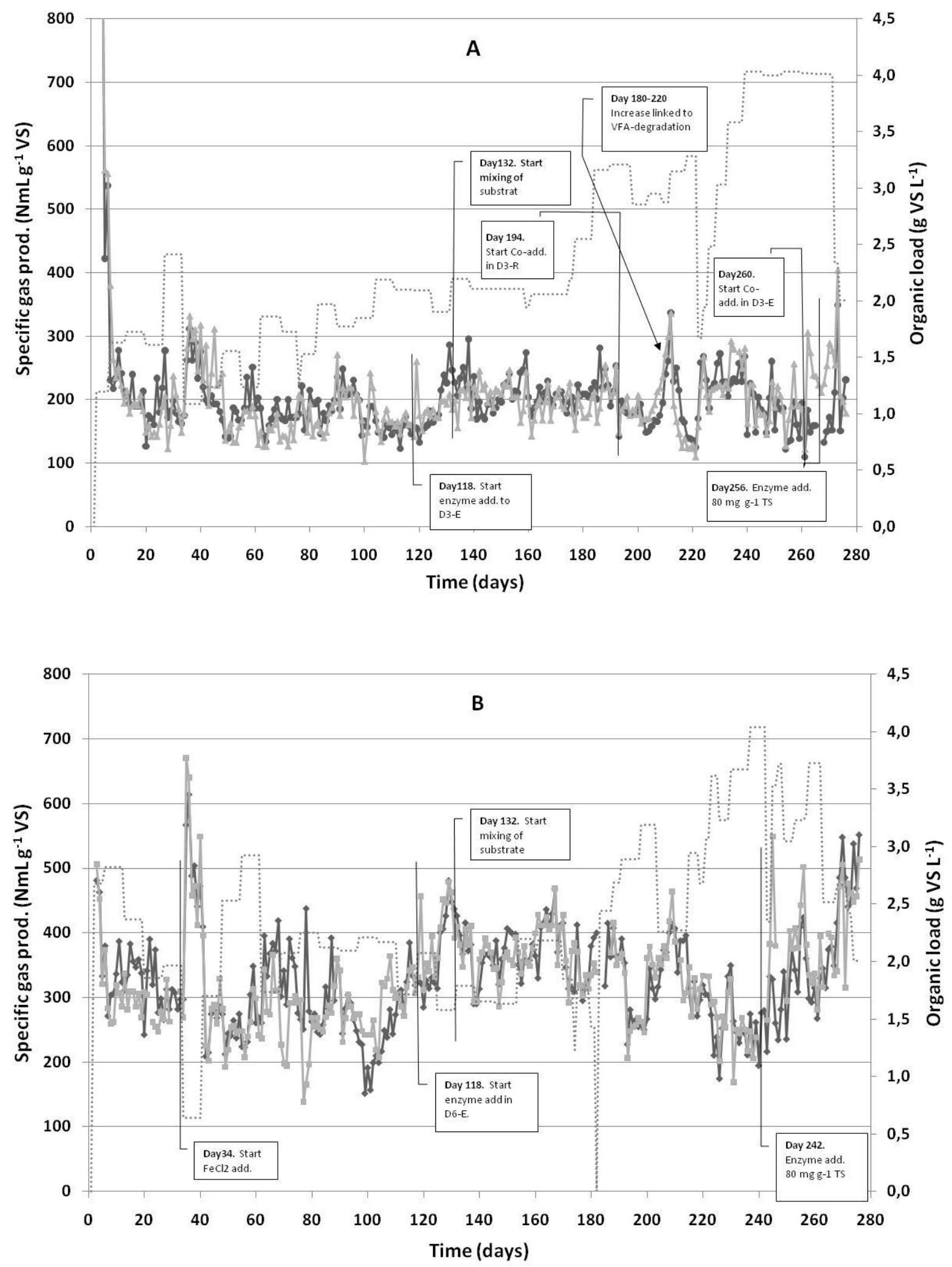

Figure 4. Specific gas production $\left(\mathrm{NmL} \mathrm{g}^{-1} \mathrm{VS}\right)$ from A) reactors $\mathrm{D} 3-\mathrm{R}(-\bullet)$ and D3-E $(\neg)$ and B) D6-R (־) and D6-E (--). Organic loading over time is shown as a dotted line. 
Table 4. Results of viscosity analysis for material from all reactors at days 110, 228 and 272 . All tests were performed at $37^{\circ} \mathrm{C}$. D3R=reference digester treating sludge from mill 3, D3E=enzyme digester treating sludge from mill 3, D6R=reference digester treating sludge from mill 6, D6E=enzyme digester treating sludge from mill

\begin{tabular}{|c|c|c|c|}
\hline Day & $\begin{array}{l}\text { Org. load } \\
\left(\mathrm{g} \mathrm{VS} \mathrm{L}^{-1}\right)\end{array}$ & Reactor & $\begin{array}{c}\text { Viscosity } \\
{\left[\mathrm{mPa}^{*} \mathrm{~s}\right] \text { at } 10 \mathrm{~s}^{-1}}\end{array}$ \\
\hline \multirow[t]{4}{*}{110} & 2.2 & D3-R & 380 \\
\hline & 2.2 & D3-E & 460 \\
\hline & 2.2 & D6-R & 181 \\
\hline & 2.2 & D6-E & 220 \\
\hline \multirow[t]{4}{*}{228} & 2.5 & D3-R & 931 \\
\hline & 2.5 & D3-E & 832 \\
\hline & 3.2 & D6-R & 412 \\
\hline & 3.2 & D6-E & 418 \\
\hline \multirow[t]{4}{*}{272} & 4.0 & D3-R & 4350 \\
\hline & 4.0 & D3-E & 2520 \\
\hline & 2.7 & D6-R & 181 \\
\hline & 2.7 & D6-E & 317 \\
\hline
\end{tabular}

D3 reactors and 96 and 77\% for D6-R and D6-E, respectively (data not shown). Thus, the dewaterability of the sludge was improved by digestion for all reactors.

\section{Limitation of organic loading}

The initial organic loadings rates (OLR) of the D-3 and D-6 reactors were 1.2 and $2.7 \mathrm{~g} \mathrm{VS} \mathrm{L}$ ${ }^{1}$ day $^{-1}$, respectively, due to differences in TS contents of the sludge from the two mills. The OLRs were planned to be increased by 0.4-0.6 $\mathrm{g} \mathrm{VS} \mathrm{L}^{-1}$ each week until a maximum was reached, judged from the levels of VFA in the reactor liquid. However, the loading increase was difficult to achieve with sludge from Mill 6, because its TS content was often too low. In addition, loadings greater than $2.0 \mathrm{~g} \mathrm{VS} \mathrm{L}^{-1}$ day $^{-1}$ increased the viscosity of the digester liquid, causing problems with mixing and maintenance of the reactors. From day 90 all four processes had developed foam covers that could not be mixed into the digester fluid by the stirring equipment. Therefore, the foam layers were shaken down by hand once a week.

From day 184, when the two D3-reactors had reached a OLR of $3.2 \mathrm{~g} \mathrm{VS} \mathrm{L}^{-1}$ day $^{-1}$, the acetate concentration increased in both reactors (Fig. 5a), peaking at 45 and $39 \mathrm{mM}$ in D3-R and D3$\mathrm{E}$ at days 207 and 203, respectively. A decrease in OLR to to $2.9 \mathrm{~g} \mathrm{VS} \mathrm{L}^{-1} \mathrm{day}^{-1}$ from day 198 to day 211, resulted in acetate concentrations below $5 \mathrm{mM}$ on day 214 in both reactors (Fig. 5a). An OLR of 3.1-3.3 $\mathrm{g} \mathrm{VS} \mathrm{L}^{-1} \mathrm{day}^{-1}$ was then resumed and applied until day 221. On day 222 the organic loading rate was decreased to $1.7 \mathrm{~g} \mathrm{VS} \mathrm{L}^{-1}$ day $^{-1}$ because of the low VS content of incoming sludge, but subsequently recovered stepwise to reach $4.0 \mathrm{~g} \mathrm{VS} \mathrm{L}^{-1} \mathrm{day}^{-1}$ on day 

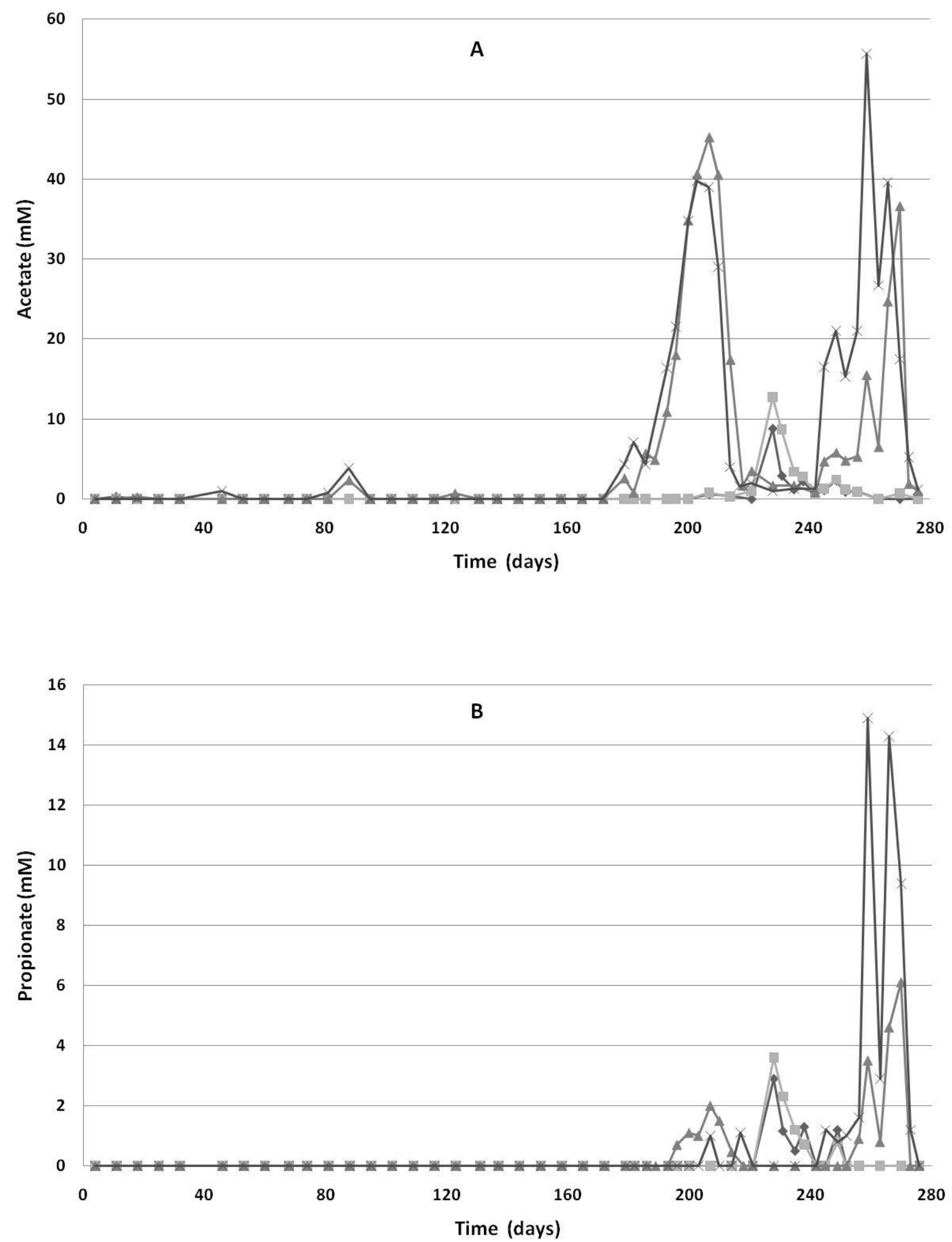

Figure 5. Concentration of $A)$ acetate $(\mathrm{mM})$ and $B)$ propionate $(\mathrm{mM})$ in $\mathrm{D} 3-\mathrm{E}(\bullet), \mathrm{D} 3-\mathrm{R}$ $(\neg)$, D6-E (־-) and D6-R (־) over time. 
239, which was maintained in both D3-reactors until day 271. The concentration of acetate increased again from day 245 (Fig. 5a), peaking at $37 \mathrm{mM}$ (day 270) in D3-R and $56 \mathrm{mM}$ (day 259) in D3-E. Propionate was detected (Fig. 5b) at a maximum concentration of $16 \mathrm{mM}$ (day 259) for D3-E and $6.1 \mathrm{mM}$ (day 270) for D3-R. In response to the first increase in acetate (days 184-214), Co was supplemented to a final concentration of $0.5 \mathrm{mg} \mathrm{L}^{-1}$ to reactor D3-R from day 192 and to reactor D-3E from day 260.

The OLR of the D-6 reactors was 2.0-2.5 $\mathrm{g} \mathrm{L}^{-1}$ day $^{-1}$ (limited by the low TS content of the sludge) during the first 200 days (Fig. 4b). From day 204, organic loading rates of 2.3-3.7 g $\mathrm{VS} \mathrm{L}^{-1}$ day $^{-1}$ were achieved by additional dewatering of sludge. Sludge with a high enough TS content to achieve an organic loading rate of $4.0 \mathrm{~g} \mathrm{VS} \mathrm{L}^{-1}$ day $^{-1}$ was obtained for a short period (days 237-242; Fig. 4b). The concentrations of acetate and propionate were less than 1 $\mathrm{mM}$ in both reactors, except for a short period, peaking at day 228 (Fig. 5) at acetate concentrations of $8.8 \mathrm{mM}(\mathrm{D} 6-\mathrm{R})$ and $13 \mathrm{mM}(\mathrm{D} 6-\mathrm{E})$ and propionate levels of $2.9 \mathrm{mM}$ and $3.6 \mathrm{mM}$, respectively.

\section{Treatment with hydrolytic enzymes, CSTR}

Hydrolytic enzymes were added to reactors D3-E and D6-E from day 118 (Fig. 4) following the dosing scheme presented in Table 3 . In order to immediately reach the target concentration of $1 \mathrm{mg} \mathrm{g}^{-1} \mathrm{TS}$ in the reactors, $80 \mathrm{mg} \mathrm{g}^{-1}$ substrate TS was included with the feed on day 118. From day 119, $1 \mathrm{mg} \mathrm{g}^{-1}$ substrate TS was added. For both reactor sets an immediate increase in biogas production took place, which, however, ceased within a week. This temporary elevation corresponded to the amounts expected from a degradation of the amount of enzyme and chealting agent added.

\section{Discussion}

The methane production potentials observed in the batch assays (100 - $200 \mathrm{NmL} \mathrm{g}^{-1}$ added VS; Fig. 1 and Table 2) were lower than the mean methane production potential assigned to the digestion of sludge at Swedish wastewater treatment plants (260 $\mathrm{Nm}^{3} \operatorname{ton}^{-1} \mathrm{VS}$; [16]), but 
roughly equal to the values for digestion of cow manure (approximately $190 \mathrm{Nm}^{3}$ / ton VS; [16]). After about 20 days incubation, sludge from Mill 6 had the highest methane production potential (Table 2) and also the highest initial methane formation rate (days 1-10 in figure 1). The data suggested that the sludge contained more readily degradable organic matter than the sludge from the other mills, which was supported by the relatively low sludge age (7 days) in the first active sludge basin of Mill 6 (Table 2). A positive effect of low sludge age on methane production potential has previously been reported by Müller et al. [17]. The cited authors compared the degradability of sludge samples with ages 3 and 13 days, and found they had $40 \%$ and $15 \%$ anaerobic degradability, respectively.

The study of the two activated sludge systems with sludge from Mill 6 with ages of 7 and 10 days (incubations $14 \&$ 15, Table 2; Fig. 2) confirmed this pattern. However, in Step 1 the wastewater inputs had a higher content of organic matter than in Step 2, and sludge from Step 2 was continuously re-circulated back to Step 1 . Therefore, there is likely a rapid uptake of available organic compounds in Step 1 by the starved sludge re-circulated from Step 2, which could have yielded an easily degradable substrate for our tests. The age of sludge from Mill 3 was also low (5 days), but formed less methane than sludge from Mill 6 (7 days old, Fig. 1), probably due to the complex water treatment at Mill 3, which comprised several different aerobic steps, including use of carrier materials, and concluded with the established practice of active sludge treatment, from which our samples were taken. It is impossible to estimate a mean sludge age over all the steps of this process.

The two dewatering steps applied to sludge from Mill 3 increased the VS content of TS from 70 to 84 and $85 \%$ and resulted in raised methane yield per g VS (Table 2). A probable explanation for these increases is that soluble salts and other non-degradable or slowly degradable constituents (e.g. humic and lignin residues) of the TS fraction were transferred into the rejected water, thus, concentrating the degradable organic matter fraction of the sludge.

The CSTR experiments resulted in methane production potentials similar to those obtained from the batch experiments after 20 days incubation; $120 \mathrm{NmL}$ compared to $110 \mathrm{NmL}$ for sludge from Mill 3 and $180 \mathrm{NmL}$ compared to about $155 \mathrm{NmL}$ for sludge from Mill 6. The variation in specific gas production (Fig. 4) was mainly due to variations in organic loading 
linked to differences in the TS content of incoming sludge from the mills, organic loading targets and the timing of substrate addition during the day.

\section{Effects of pre-treatment}

The results from ultrasonic treatments performed in the batch experiments (Table 2) showed that energy inputs greater than $15 \mathrm{Wh} \mathrm{L}^{-1}$ sludge were needed to increase the methane production potential. Only an input of $30 \mathrm{Wh} \mathrm{L}^{-1}$ generated a detectable increase, primarily in the initial methane formation rate (Fig. 3; days 1-8). The initial effect on the methane formation rate implies that either the retention time of a full-scale process can be shortened while retaining the same methane yield, or that an improved methane yield can be obtained with the original retention time. The energy input in this case is, however, large compared to the energy recovered by increased methane formation. Using data from this study, an energy input of $30 \mathrm{kWh}$ was estimated to generate an increase of $1 \mathrm{~m}^{3}$ of methane per $\mathrm{m}^{3}$ of digested sludge, assuming 5\% TS content. Since the energy content of the methane thus generated would be approximately $10 \mathrm{kWh}$, this equates to around $30 \%$ of the energy consumed by ultrasonic treatment.

Studies of the effects of ultrasonic treatment on sludge from sewage wastewater treatment plants have shown positive effects on the particle size of municipal sludge [18] and the efficiency of anaerobic digestion, e.g. [19], ( 50\% increase), [20](15\% increase) and [21](13$21 \%$ increase). However, the use of different units of energy input makes it difficult to compare the studies. Kyllönen et al. [22] investigated the effects of ultrasound on the size of particulate matter and the sedimentation of sludge from wastewater treatment in the pulp and paper industry, but the methane production potential was not evaluated and the amount of energy applied was not reported. Samples were treated at $50 \mathrm{kHz}$, which is high compared to $20 \mathrm{kHz}$ applied in the present study. Wood et al. [23] described an investigation in which three pre-treatment methods were applied to sludge from the pulp industry: heat $\left(170^{\circ} \mathrm{C}\right.$ for 1 h); alkali and heat $\left(\mathrm{pH} 12,140^{\circ} \mathrm{C}\right.$ for $\left.1 \mathrm{~h}\right)$ and ultrasound $\left(20 \mathrm{kHz}, 1 \mathrm{~W} \mathrm{~mL}{ }^{-1}\right.$ for $30 \mathrm{~min}$, corresponding to an energy input of about $500 \mathrm{Wh} \mathrm{L}^{-1}$ ). The first two treatments increased the digestibility of the sludge, but the effect of the ultrasound treatment was marginal; only a small increase in the initial methane formation rate was observed. Thus, according to Wood et al. [23] and from the results of the present study, it can be concluded that ultrasound is not a suitable pre-treatment method for sludge from the pulp and paper industry. 
The positive effect ( $50 \%$ or $50 \mathrm{NmL} \mathrm{CH}_{4} \mathrm{~g}^{-1}$ VS increase) of hydrolytic enzymes on the overall methane production potential (Fig. 3) in the batch experiments led to further evaluation in the laboratory-scale reactor experiment. However, apart from the first week of application (Fig. 4; days 119-12) no effect was observed until the dose was increased from 18 to $80 \mathrm{mg}$ enzyme per $\mathrm{g}$ added TS. This dose was maintained for two weeks for both reactors and resulted in an enhanced gas production of about 15\% from D6-E and about 22\% from D3E, when corrected for simultaneous degradation of acetate and propionate during this period. However, as pointed out in the results section, the effect upon the batch tests and CSTRs can be attributed to the carbon and energy contents of the enzyme and chelating mixtures. No effect of mixing and freezing of the sludge was observed on the biogas yields (Fig. 4) showing that these treatments did not have any effect towards increasing the sludge digestibility and thus did not interfere with possible effects of the enzyme additions.

The low impact of enzyme addition on methane production from the sludge of the two mills may be due to the high viscosity of the reaction mixture, which could limit the availability of sites to which the enzymes bind. Wawrzynczyk et al. [24] investigated the influence on enzymatic activity of cation-binding compounds that prevent flocculation or biofilm formation. The minimization of agglomeration maximizes chemical availability (e.g. for enzyme binding) and probably also decreases liquid viscosity. The chelating agent used in the present study may have decreased the viscosity of the liquid in reactor D3-E (Table 4; day 272), while in reactor D6-E the viscosity was higher than in D6-R. The observed results appear to contradict those of Roman et al. [12] and Davidsson et al. [11], who found that enzyme treatment improved the digestibility of primary sewage sludge. The apparently conflicting results might be due to differences in the characteristics of primary and activated sludge, the sources of sludge and the high viscosity of the substrate during digestion in the present study.

\section{Cobalt addition}

A lack of macro- and micro nutrients can limit microbial growth in biogas reactors [25] and can therefore reduce the maximum organic loading possible. A loading limitation is often reflected in increased levels of VFA, primarily acetate and propionate. In such cases, the loading capacity of the system can be improved by adding more of the limiting nutrients, 
which will improve the microbial growth rate. Cobalt has in many cases been shown to be rate-limiting and its subsequent addition has been reported to affect the transformation of VFAs [26-28]. The present authors' experience of the addition of $\mathrm{Co}$ is that levels below 0.1 $\mathrm{mg} \mathrm{Co} \mathrm{L}{ }^{-1}$ reactor volume can be rate-limiting at loadings exceeding $2.5 \mathrm{~g} \mathrm{VS} \mathrm{L}^{-1}$ (unpublished results). In this study Co was added to reactor D3-R when the VFA-levels began to rise at an organic loading of $3.2 \mathrm{~g} \mathrm{VS} \mathrm{L}^{-1}$ and day. However, no effect could be claimed because the VFA were degraded again at similar rates in both reactors. The addition of Co continued and, when the organic loading reached $4.0 \mathrm{~g} \mathrm{VS} \mathrm{L}^{-1}$, a clear difference in VFA concentrations was observed between the reactors (Fig. 5), with lower VFA levels in D3-R. Co was also added to D3-E from day 260 and the concentration of acetate was observed to decrease from day 266. The VFA concentrations increased in D3-R but not to the same extent, the increase occurred later and the VFA concentration decreased again before completion of the experiment (Fig. 5). To the best of our knowledge, this is the first report of the effect of Co on the digestion of activated sludge from the pulp- and paper industry, which indicates a potential for improved biogas production from these kinds of substrates.

\section{Dewatering}

The dewatering of the activated sludge was improved by digestion, which is in agreement with observations by Kopp et al. [29] and Xu et al. [30]. The latter demonstrated a correlation between sludge dewaterability and molecular weight of the sludge compounds. A decrease in the molecular weight of the loosely bound EPS (extracellular polymeric substances) fraction led to increased dewaterability. However, in a similar study by Müller et al. [17], sludge digestion had no observed effect on the dewaterability of sewage sludge. The different results are likely explained by variations in VS characteristics and degree of reduction of the VS content [8].

\section{Viscosity}

The technical problems associated with mixing of the reactor sludge and addition of the activated sludge substrate was related to the high viscosity of the dewatered substrate and the process liquid. To reduced the viscosity and permit higher organic loads pre-treatment methods could be explored, such as deflocculation, to break down agglomerations. Further investigation is needed to assess the potential utility of such approaches. Gas production could 
also be improved by co-digestion with an energy-rich substrate. This approach would probably also reduce the viscosity.

\section{Conclusions}

The biogas potential of sludge from wastewater treatment processes at six mills varied between 100 and $200 \mathrm{~mL} \mathrm{CH}_{4} \mathrm{~g}^{-1}$ VS. Sludge age affected the biogas production, since younger sludge has a higher biogas potential, but recirculation within the water treatment system probably influenced this result. The evaluated pre-treatments (ultrasonic energy and hydrolytic enzymes) did not elicit detectable positive effects at realistic input levels. Co improved the transformation of acetate, suggesting that there is scope for process improvements by the addition of trace nutrients. The high viscosity of the reactor liquid was the major obstacle to increasing the organic loading.

\section{Acknowledgement}

This study was supported by the Swedish Thermal Engineering Research Institute (Värmeforsk).

\section{References}

[1] M. Krogerus, E. Tennander, and Å. Sivard, Sammanställning av erfarenheter från hantering av slam inom skogsindustrin., Värmeforsk Raport 666, Stockholm1999.

[2] V. Alonso, A. Martin, R. Borja, and A. Chica, Anaerobic treatment of wastewater produced in the manufacture of cellulosic pulp from wheat straw, Environ Technol, 14 (1993), pp. 11451153.

[3] A. P. Buzzini, E. P. Gianotti, and E. C. Pires, UASB performance for bleached and unbleached kraft pulp synthetic wastewater treatment, Chemosphere, 59 (2005), pp. 55-61.

[4] S. Chinnaraj and G. Venkoba Rao, Implementation of an UASB anaerobic digester at bagassebased pulp and paper industry, Biomass Bioenerg, 30 (2006), pp. 273-277.

[5] M. Lerner, N. Stahl, and N. Galil, Aerobic vs. anaerobic-aerobic biotreatment: Paper mill wastewater, Environ Eng Sci, 24 (2007), pp. 277-285.

[6] K. Xie, H. J. Lin, B. Mahendran, D. M. Bagley, K. T. Leung, S. N. Liss, and B. Q. Liao, Performance and fouling characteristics of a submerged anaerobic membrane bioreactor for kraft evaporator condensate treatment, Environ Technol, 31 (2010), pp. 511-521.

[7] A. Elliott and T. Mahmood, Pretreatment technologies for advancing anaerobic digestion of pulp and paper biotreatment residues, Water Res, 41 (2007), pp. 4273-4286. 
[8] J. I. Houghton, T. Stephenson, and J. Quarmby, The impact of digester retention time on microbial extracellular polymer production and sludge dewaterability, Environ Technol, 21 (2000), pp. 1157-1165.

[9] A. T. W. M. Hendriks and G. Zeeman, Pretreatments to enhance the digestibility of lignocellulosic biomass, Biores Technol, 100 (2008), pp. 10-18.

[10] J. Mata-Alvarez, S. Macé, and P. Llabrés, Anaerobic digestion of organic solid wastes. An overview of research achievements and perspectives, Biores Technol, 74 (2000), pp. 3-16.

[11] Å. Davidsson, J. Wawrzynczyk, O. Norrlöw, and J. L. C. Jansen, Strategies for enzyme dosing to enhance anaerobic digestion of sewage sludge, J Res Sci Technol, 4 (2007), pp. 1-7.

[12] H. J. Roman, J. E. Burgess, and B. I. Pletschke, Enzyme treatment to decrease solids and improve digestion of primary sewage sludge, Afr J Biotechnol, 5 (2006), pp. 963-967.

[13] Q. Yang, K. Luo, X.-M. Li, D.-B. Wang, W. Zheng, G.-M. Zeng, and J.-J. Liu, Enhanced efficiency of biological excess sludge hydrolysis under anaerobic digestion by additional enzymes, Bioresource Technology, 101 (2010), pp. 2924-2930.

[14] A. Karlsson, J. Ejlertsson, D. Nezirevic, and B. H. Svensson, Degradation of phenol under meso- and thermophilic, anaerobic conditions, Anaerobe, 5 (1999), pp. 25-35.

[15] S. Jonsson and H. Borén, Analysis of mono- and diesters of o-phthalic acid by solid-phase extractions with polystyrene-divinylbenzene-based polymers, J Chromatogr A, 963 (2002), pp. 393-400.

[16] M. Linné, A. Ekstrandh, R. Englesson, E. Persson, L. Björnsson, and M. Lantz, Den svenska biogaspotentialen från inhemska restprodukter, Biomil and Envirum, Lund2008.

[17] J. Müller, G. Lehne, J. Schwedes, S. Battenberg, R. Näveke, J. Kopp, N. Dichtl, A. Scheminski, R. Krull, and D. C. Hempel, Disintegration of sewage sludges and influnce on anaerobic digestion, Water Sci Technol, 38 (1998), pp. 425-433.

[18] T. Mao, S.-Y. Hong, K.-Y. Show, J.-H. Tay, and D.-J. Lee, A comparison of ultrasound treatment on primary and secondary sludges, Water Sci Technol, 50 (2004), pp. 91-97.

[19] F. Hogan, S. Mormede, P. Clark, and M. Crane, Ultrasonic sludge treatment for enhanced anaerobic digestion, Water Sci Technol, (2004), pp. 25-32.

[20] J. Quarmby, J. R. Scott, A. K. Mason, G. Davies, and S. A. Parsons, The application of ultrasound as a pre-treatment for anaerobic digestion, Envion Tech, 20 (1999), pp. 11551161.

[21] C. D. Müller, M. Abu-Orf, C. D. Blumenschein, and J. T. Novak, A comparative study of ultrasonic pretreatment and an internal recycle for the enhancement of mesophilic anaerobic digestion, Wat Environ Res, 81 (2009), pp. 2398-2410.

[22] H. L. Kyllönen, M. K. Lappi, R. T. Thun, and A. H. Mustranta, Treatment and characterization of biological sludges from the pulp-and paper industry, Water Sci Technol, 20 (1988), pp. 183-192.

[23] N. Wood, H. Tran, and E. Master, Pretreatment of pulpmill secondery sludge for high-rate anaerobic conversion to biogas, Biores Technol, 100 (2009), pp. 5729-5735.

[24] J. Wawrzynczyk, M. Recktenwald, O. Norrlöw, and E. S. Dey, The function of cation-binding agents in the enzymatic treatment of municipal sludge, Water Res, 42 (2008), pp. 1555-1562.

[25] M. Takashima and R. E. Speece, Mineral requirements for methane fermentation, Crit Rev Env Contr, 19 (1989), pp. 465-479.

[26] A. Jarvis, A.. Nordberg, T. Jarlsvik, B. Mathisen, and B. H. Svensson, Improvment of a grassclover silage-fed biogas process by the addition of cobalt, Biomass Bioenerg, 12 (1997), pp. 453-460.

[27] K. Kida, T. Shigematsu, J. Kijima, M. Numaguchi, Y. Mochinaga, N. Abe, and S. Morimura, Influence of Ni2+ and $\mathrm{Co} 2+$ on methanogenic activity and the amounts of coenzymes involved in methanogenesis, J Biosci Bioeng, 91 (2001), pp. 590-595. 
[28] M. Kim, Y.-H. Ahn, and R. E. Speece, Comparative process stability and effeciency of anaerobic digestion; mesophilic vs. thermophilic, Water Res, 36 (2002), pp. 4369-4385.

[29] J. Kopp, J. Müller, N. Dichtl, and J. Schwedes, Anaerobic digestion and dewatering characteristics of mechanically disintegrated excess sludge, Water Science and Technology, 36 (1997), pp. 129-136.

[30] H. Xu, P. He, and S. Liming, Characteristics of organic matters during anaerobic digestion of ultrasonically pretreated sludge and the effects on sludge dewaterability, J Res Sci Technol, 6 (2009), pp. 119-124. 